УДК $340+342.7$

DOI https://doi.org/10.32837/apdp.v0i90.3206

Н. В. Бочарова, В. М. Шкабаро, Ю. С. Палєева

\title{
ПРИНЦИПИ І ПРІОРИТЕТИ РАДИ СВРОПИ ЩОДО ЗАХИСТУ ПРАВ ЛЮДИНИ В ІНФОРМАЦІЙНОМУ СУСПІЛЬСТВІ: ІНІЦІАТИВИ ІНФОРМАЦІЙНЕ СУСПІЛЬСТВО: ФОКУС 2021
}

Питання правового регулювання Інтернету набувають дедалі більшої актуальності в умовах поширення інформаційно-комунікаційних технологій. Цифровізація соціуму проявляється в широкому застосуванні високошвидкісного індустріального Інтернету (internet of things), інтегрованих промислових мереж і штучного інтелекту, сервісів автоматичної ідентифікації, збору й обробки глобальних баз даних (big data), хмарних сервісів і обчислень (doud computing), «розумних" робототехнічних комплексів (smart everything), у розвитку соціальних мереж, різноманітних IT-платформ і сервісів у цифровому середовищі. Нова цифрова реальність впливає на розвиток державних і суспільних інститутів, а також на правовий статус особи. Проблема захисту фундаментальних прав і свобод користувачів Інтернету стає умовою подальшого розвитку інформаційного суспільства, оскільки постійно зростає кількість людей, які пов'язані зі створенням, зберіганням, переробкою та поширенням інформації. Крім того, інформаційне суспільство також створює нові права людини, так звані інформаційні права і свободи (digital rights), які охоплюють сукупність правомочностей людини у сфері застосування інформаційних технологій і сервісів, виробництва й забезпечення захисту інформації, а також доступу до Інтернету.

Питання дослідження прав людини в Інтернеті висвітлюються в роботах багатьох вітчизняних авторів. Серед них - А. Пазюк, О. Барабаш, I. Сопілко, I. Забара, П. Сухорольский, А. Костенко, Ю. Размєтаєва та інші.

Метою статті є аналіз новітніх правозахисних ініціатив Ради Свропи щодо правового регулювання в умовах розвитку інформаційних технологій і прискореного технологічного розвитку.

Пропонована проблематика досліджується у вітчизняній правничій літературі вперше.

Рада Європи - перша європейська міжнародна організація, створена у 1949 році, своєю головною задачею оголосила захист прав людини. 3 цією метою було ухвалено Конвениію про захист прав людини і основоположних свобод і забезпечено механізм її реалізації.

Розвиток інформаційних технологій в останній чверті XX століття визначив не тільки економічний потенціал сучасних держав, але зумовив і суспільно-політичні процеси, що безпосередньо торкаються прав людини. У зв'язку з цим постала задача оновлення каталогу прав людини з урахуванням змін, викликаних технологічними перетвореннями. Активну роль у процесі визначення правових цінностей і пріоритетів інформаційного суспільства відіграє Рада Європи. 
Вплив інформаційно-комунікаційних технологій (далі - IКТ) на права людини і цінності демократії був вперше розглянутий на європейській конференції міністрів країн Ради Європи в Греції у грудні 1997 р. Створений згодом Kолітет експертів РЕ по інформаиійному суспільству розробив проєкт документа, який було ухвалено у травні 2005 р. під назвою Декларація комітету міністрів про права людини і верховенство права в інформаційному суспільстві [1].

Основна ідея Декларащї полягає в тому, що такі цінності, як права людини, демократія, верховенство права, суспільна згода і довіра між людьми, зберігаються під час застосування інформаційно-комунікаційних технологій. У документі наголошено, що всі права, закріплені в Свропейській конвенції про захист прав людини i основоположних свобод, у повному обсязі зберігають свою силу в інформаційну епоху і повинні бути захищені надалі незалежно від нових технологічних досягнень. Водночас інформаційні технології можуть запропонувати нові можливості для реалізації прав людини, а відсутність або обмеження доступу до ІКТ може позбавити людей можливості реалізувати свої громадянські права. По суті, перераховані в Декларацї̈ права і свободи повністю або частково повторюють список, приведений в багатьох інших аналогічних документах, зокрема в Міжнародному біллі про права людини. Проте є і відмінності. Уперше було порушено питання державної і приватної цензури, захисту особистої інформації, навчання людей з метою надання допомоги в оцінці якості інформації. Крім цього, в документі йде мова про етику у медіа сфері і використання інформаційних технологій для розвитку демократії і свободи зібрань у кіберпросторі.

Велике методологічне значення має Реколендація Комітету міністрів Ради Європи щодо інтернет-свободи (Recommendation CM/Rec(2016)5 of the Committee of Ministers to member States on Internet freedom. Adopted by the Committee of Ministers on 13 April 2016 at the 1253rd meeting of the Ministers' Deputies). В документі зокрема зазначено, що Європейська конвенція про захист прав людини і основоположних свобод (ETS № 5, далі - Конвенція) застосовується як в автономному режимі (офлайн), так і онлайн. Держави-члени Ради Свропи мають негативні і позитивні зобов'язання щодо дотримання, захисту і заохочення прав людини та основних свобод в Інтернеті. Водночас «інтернет-свобода розуміється як здійснення і користування в Інтернеті правами людини і основними свободами, а також їх захист відповідно до Конвениї та Міжнародного пакту про гроладянські і політичні права. Держави-члени Ради Європи повинні вжити активний підхід до імплементації Конвениї та інших стандартів Ради Свропи щодо Інтернету. Розуміння свободи Інтернету повинно бути всеосяжним і твердо Ірунтуватися на цих стандартах».

Наприкінці 2020 р. в умовах святкування 70-річчя Європейської конвениї̈ про захист прав людини і основоположних свобод в Раді Європи було підготовлено аналітико-прогностичний документ Інформаційне суспільство: Фокус 2021 (Information Society: Focus 2021) [2], в якому сконцентровано принципи подальшого розвитку захисту прав людини в специфічних умовах технологічного прогресу і визначено сучасну правову базу, створену Радою Європи для юридичного забезпечення правозахисного руху. 
Серед напрямів захисту прав людини в цифровому середовищі визначено:

- Захист свободи вираження поглядів (Defending Freedom of Expression);

- Посилення цифрового управління (Enhancing Digital Governance);

- Вивчення штучного інтелекту (Exploring Artificial Intelligence);

- Захист конфіденційності (Safeguarding Privacy);

- Боротьба з кіберзлочинністю (Combating Cybercrime).

Стандарти захисту свободи вираження поглядів сформульовані у ст. 10 Європейській конвениї̈ про захист прав людини і основоположних свобод. Принципи, що стосуються свободи вираження поглядів, додатково встановлюються прецедентною практикою Європейського суду з прав людини, яка неухильно зростає [3]. Керівний комітет Ради Європи з питань засобів масової інфорлацї та інформаційного суспільства (Council of Europe Steering Committee on Media and Informational Society - CDMSI ) представить у 2021 році свої керівні принципи управління засобами масової інформації та комунікаціями, щоб розв’язати питання про перехід від усталених інформаційних каналів до соціальних мереж та пов'язаних із ними ризиків, серед яких маніпулювання громадською думкою, відсутність довіри громадськості, невпорядкованість інформації. Планується оголосити нові вимоги до політики щодо пріоритетності контенту, що становить суспільний інтерес, на відповідних соціальних і пошукових платформах та інших агрегаторах новин, а також рекомендації щодо виборчої комунікації та висвітлення виборчих кампаній у ЗМІ. Пропонуються також нові правові інструменти боротьби з мовою ненависті. Конференція міністрів, відповідальна за ЗМІ та інформаційне суспільство обговорить у червні 2021 року шляхи подолання радикальних змін, спричинених новою хвилею технологій, які вплинули на ЗMI та інтернет-середовище в плані здійснення свободи вираження поглядів.

Під управлінням Інтернетом розуміють розроблення та застосування урядами, приватним сектором і громадянським суспільством спільних принципів, норм, правил, процедур ухвалення рішень і програм, що формують еволюцію використання Інтернету. У рамках Ради Європи був створений Посібник з прав людини для користувачів Інтернету, прийнятий Комітетом міністрів у Страсбурзі 16 квітня 2014 року. Він був розроблений після консультацій з широким колом зацікавлених сторін (stakeholders), включаючи уряди, приватні компанії, організації громадянського суспільства, представників технічного співтовариства та наукових кіл. Виходячи з того, що права людини та основні свободи застосовуються однаково як в режимі офлайн, так і в Інтернеті, Посібник рекомендує дотримуватися прав людини в кіберпросторі на основі Європейської конвенції з прав людини та інших документів Ради Європи.

У межах Ради Свропи було розроблено Стратегію управління Інтернетол на 2016-2019 рр., яка спрямована на забезпечення державної політики в Інтернеті, орієнтованої на людей і сприяння побудові демократії в Інтернеті, захисту користувачів Інтернету та забезпечення поваги прав людини [4]. Інтернет повинен втілювати простір свободи, здійснення та користування основними правами, стимулювати демократичні процеси. 
Новелою останнього часу є акцент на ролі інтернет-провайдерів у наданні та налаштуванні змісту в Інтернеті, управлінні даними користувачів, а також впровадження обмежувальних політик або програм спостереження. Рада Європи доручила групі експертів розробити політику, засновану на принципі верховенства права, щодо відносин між державними органами та інтернет-посередниками стосовно зобов'язань та відповідальністю з дотриманню прав людини. Паралельно проводиться робота щодо формулювання правових, соціальних та етичних міркувань, пов'язаних з алгоритмами та автоматизованою обробкою технічних даних. Досліджуються такі сфери, як соціальні конструкції навколо алгоритмів, вплив алгоритмів на права людини, а також механізми відповідальності за управління Інтернетом, прозорість та етика управлінської діяльності. Здійснено кроки щодо встановлення основи для партнерства між Радою Європи та інтернет-компаніями з метою створення простору спільних дій з питань, пов'язаних з реалізацією прав людини в Інтернеті. Рада Європи, таким чином, спрямована на сприяння діалогу між інтернет-компаніями та іншими зацікавленими сторонами.

Проблема забезпечення прав людини у зв'язку з використання штучного інтелекту є однією з центральних для сучасної правозахисної діяльності Ради Європи. Для координації зусиль експертного середовища був створений міждисциплінарний спеціальний Комітет з питань штучного інтелекту (Ad-hoc Committee on Artificial Intelligence - CAHAI), в завдання якого входить створення правової бази для розроблення, проєктування та застосування штучного інтелекту на основі стандартів прав людини, демократії та верховенства права. У 2019 році Комітет міністрів видав Декларацію про маніпулятивні можливості алгоритлічних процесів та рекомендації щодо алгоритмічного впливу на права людини [5]. У Декларацї міністри висловили побоювання, що особи через використання передових цифрових технологій, зокрема методів мікронацілювання, можуть не мати змоги формулювати свої думки та приймати рішення незалежно від автоматизованих систем, і що вони можуть навіть піддаватися маніпуляціям не лише стосовно їхнього економічного вибору, а й їх соціальної та політичної поведінки. Комітет міністрів закликав 47 держав-членів розглянути «потребу в додаткових захисних системах, що стосуються даних, які виходять за межі сучасних уявлень про захист і конфіденційність персональних даних і мають значний вплив стосовно цільового використання даних на суспільство та щодо здійснення прав людини» .

Конвениї про захист фізичних осіб під час автоматизованої обробки персональних даних (більш відома як Конвенція No.108) понад 40 років [6]. Вона була модернізована у 2018 році для адаптації до нових реалій інформаційного суспільства та посилення ефективності її впровадження. Протокол внесення злін до Конвениї 108 (CETS № 223) має набрати чинності в наступні роки. Ключовими цілями змін є захист людської гідності та цілісності у цифрову епоху. Конвенція 108+ (тобто з поправками, внесеними Протоколом), як вважається, стає глобальним стандартом конфіденційності у цифровому середовищі.

Насамкінець зазначимо, що продовжують працювати правозахисні положення Конвениї про кіберзлочинність (Budapest Convention of the Council 
of Europe - ETS No.185), яка була доповнена Додатковим протоколом щодо криміналізації дій расистського та ксенофобського характеру, вчинених через комп'ютерні систели [7].

Проаналізовані особливості сучасних підходів до забезпечення і захисту прав людини в інформаційному суспільстві повинні враховуватися українським законодавцем при розробці норм національної системи захисту.

\section{Jimepamypa}

1. Declaration of the Committee of Ministers on Human Rights and the Rule of Law in the Information Society CM (2005) final. Publ. N060508/b/2.

2. Information Society: Focus 2021. URL: https://rm.coe.int/leaflet-information-society-focus-2021en-october-2020/1680a0cd58.

3. Freedom of Expression, the Media and Journalists - Case-law of the European Court of Human Rights - 4th edition European Audiovisual Observatory, Strasbourg 2017. URL: https://rm.coe.int/ freedom-of-expression-the-media-and-journalists-iris-themes-vol-iii-de/16807c1181.

4. Див. докладно аналітичний огляд Internet Governance. URL: https://rm.coe.int/leaflet-internetgovernance-en-rev/1680909521.

5. Declaration by the Committee of Ministers on the manipulative capabilities of algorithmic processes. URL: https://www.coe.int/en/web/data-protection/-/declaration-by-the-committee-of-ministers-on-themanipulative-capabilities-of-algorithmic-processes.

6. Конвенція про захист осіб у зв'язку з автоматизованою обробкою персональних даних. Страсбург, 28 січня 1981 року. URL: .ua/laws/show/994_326.

7. Additional Protocol to the Convention on Cybercrime, concerning the criminalisation of acts of a racist and xenophobic nature committed through computer systems. URL: https://www.coe.int/en/web/ conventions/full-list/-/conventions/treaty/189.

\section{Анотація}

Бочарова Н. В., Шкабаро В. М., Палєєва Ю.С. Принципи і пріоритети Ради Європи щодо захисту прав людини в інформаційному суспільстві: ініціативи Інформаційне суспільство: Фокус 2021. Стаття.

Статтю присвячено аналізу новітніх правозахисних ініціатив Ради Європи щодо правового регулювання в умовах розвитку інформаційних технологій і прискореного технологічного розвитку. Пропонована проблематика досліджується у вітчизняній правничій літературі вперше.

Зазначено, що наприкінці 2020 р. в умовах святкування 70-річчя Європейської конвенції про захист прав людини і основоположних свобод у Раді Європи було підготовлено аналітико-прогностичний документ Інформаиійне суспільство: Фокус 2021 (Information Society: Focus 2021), в якому сконцентровано принципи подальшого розвитку захисту прав людини в специфічних умовах технологічного прогресу та визначено сучасну правову базу, яку створила Рада Європи для юридичного забезпечення правозахисного руху. Серед напрямів захисту прав людини в цифровому середовищі визначено такі: захист свободи висловлення поглядів (Defending Freedom of Expression), посилення цифрового управління (Enhancing Digital Governance), вивчення штучного інтелекту (Exploring Artificial Intelligence), захист конфіденційності (Safeguarding Privacy), боротьба з кіберзлочинністю (Combating Cybercrime).

Керівний комітет Ради Європи з питань засобів масової інформаиї̈ та інформаційного суспільства (Council of Europe Steering Committee on Media and Informational Society - CDMSI) розробляє керівні принципи управління засобами масової інформації та комунікаціями, щоб розв'язати питання про перехід від усталених інформаційних каналів до соціальних мереж і пов'язаних із ними ризиків, серед яких - маніпулювання громадською думкою, брак довіри громадськості, невпорядкованість інформації. Аналізується Стратегія управління Інтернетом на 2016-2019 рр., яка спрямована на забезпечення державної політики в Інтернеті, орієнтованої на людей і сприяння побудові демократії в Інтернеті, захист користувачів Інтернету та забезпечення поваги прав людини. Проблема забезпечення прав людини через використання штучного інтелекту є однією з центральних для сучасної правозахисної діяльності Ради Європи. Для координації зусиль експертного середовища було створено міждисциплінарний спеціальний Комітет із питань штучного інтелекту (Ad-hoc Committee 
on Artificial Intelligence - CAHAI), до завдань якого входить створення правової бази для розроблення, проєктування та застосування штучного інтелекту на основі стандартів прав людини, демократії та верховенства права. Розглянуто питання модернізації Конвениії про захист фізичних осіб під час автоматизованої обробки персональних даних для адаптації до нових реалій інформаційного суспільства та посилення ефективності їі впровадження. Проаналізовані особливості сучасних підходів до забезпечення та захисту прав людини в інформаційному суспільстві повинні враховуватися українським законодавцем під час розроблення норм національної системи захисту.

Ключові слова: права людини, інформаційне суспільство, Інтернет, Рада Європи.

\section{Summary}

Bocharova N. V., Shkabaro V. M., Paleeva Y. S. Principles and priorities of the Council of Europe for the protection of human rights in the information society: initiatives Information society: Focus 2021. Article.

The article is devoted to the analysis of the latest human rights initiatives of the Council of Europe on legal regulation in the conditions of information technology development and accelerated technological development. The proposed issues are studied in the domestic legal literature for the first time.

It is noted that at the end of 2020 , in celebration of the 70 th anniversary of the European Convention for the Protection of Human Rights and Fundamental Rights, the Council of Europe prepared an analytical and prognostic document Information Society: Focus 2021, which concentrates the principles of further protection human rights in the specific context of technological progress and defined the existing legal framework established by the Council of Europe for the legal support of the human rights movement. Areas of human rights protection in the digital environment include: Defending Freedom of Expression, Enhancing Digital Governance, Exploring Artificial Intelligence, Safeguarding Privacy, and Combating Cybercrime).

The Council of Europe Steering Committee on Media and Information Society (CDMSI) is developing guidelines for managing the media and communications to address the transition from established information channels to social networks and social networks. associated risks, including manipulation of public opinion, lack of public confidence, disorder of information. The Internet Governance Strategy for 2016-2019, which aims to ensure public policy on the Internet, focused on people and promote democracy on the Internet, protect Internet users and ensure respect for human rights, is analyzed. The issue of human rights in relation to the use of artificial intelligence is one of the central issues of modern human rights work in the Council of Europe. An interdisciplinary Ad hoc Committee on Artificial Intelligence ( $C A H A I)$ has been established to coordinate the efforts of the expert community, with the task of creating a legal framework for the development, design and application of artificial intelligence based on human rights, democracy and supremacy standards. rights. The issues of modernization of the Convention for the Protection of Individuals with regard to Automatic Processing of Personal Data in order to adapt to the new realities of the information society and increase the effectiveness of its implementation are considered. The analyzed features of modern approaches to ensuring and protecting human rights in the information society should be taken into account by the Ukrainian legislator when developing the norms of the national protection system.

Key words: human rights, information society, Internet, Council of Europe. 